\title{
Communication Technologies for Vehicles
}

Proceedings of the 8th International Workshop, Nets4Cars/Nets4Trains/Nets4Aircraft 2015

Kassab, Mohamed; Berbineau, Marion; Vinel, Alexey; Jonsson, Magnus; Garcia, Fabien; Soler, José

Link to article, DOI:

10.1007/978-3-319-17765-6

Publication date:

2015

Document Version

Publisher's PDF, also known as Version of record

Link back to DTU Orbit

Citation (APA):

Kassab, M. (Ed.), Berbineau, M. (Ed.), Vinel, A., Jonsson, M. (Ed.), Garcia, F. (Ed.), \& Soler, J. (Ed.) (2015). Communication Technologies for Vehicles: Proceedings of the 8th International Workshop,

Nets4Cars/Nets4Trains/Nets4Aircraft 2015. Springer. Computer Communication Networks and Telecommunications Vol. 9066 https://doi.org/10.1007/978-3-319-17765-6

\section{General rights}

Copyright and moral rights for the publications made accessible in the public portal are retained by the authors and/or other copyright owners and it is a condition of accessing publications that users recognise and abide by the legal requirements associated with these rights.

- Users may download and print one copy of any publication from the public portal for the purpose of private study or research.

- You may not further distribute the material or use it for any profit-making activity or commercial gain

- You may freely distribute the URL identifying the publication in the public portal 


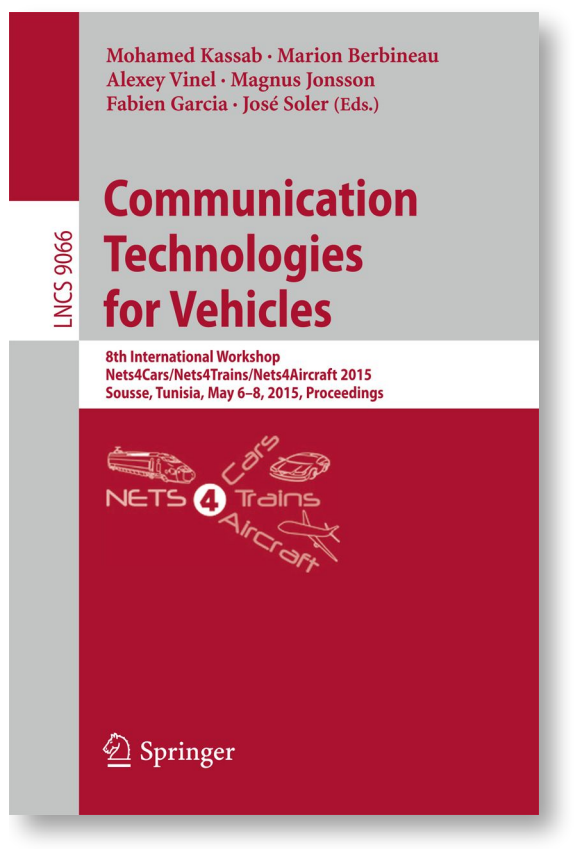

2015, XII, 241 p. 45 illus.

\section{Printed book}

\section{Softcover}

- 48,00€|£43.99|\$72.00

- *51,36€ (D) $|52,80 €(A)|$ CHF 54.50

\section{eBook}

\section{Available from your library or}

- springer.com/shop

my Mycopy

\section{Printed eBook for just}

- $€ \mid \$ 24.99$

- springer.com/mycopy
M. Kassab, M. Berbineau, A. Vinel, M. Jonsson, F. Garcia, J. Soler (Eds.)

\section{Communication Technologies for Vehicles}

8th International Workshop, Nets4Cars/Nets4Trains/Nets4Aircraft 2015, Sousse, Tunisia, May 6-8, 2015. Proceedings

Series: Computer Communication Networks and Telecommunications, Vol. 9066

This book constitutes the proceedings of the 8th International Workshop on Communication Technologies for Vehicles, Nets4Cars/Nets4Trains/Nets4Aircraft 2015, held in Sousse, Tunisia, in May 2015. The 20 papers presented in this volume were carefully reviewed and selected from 27 submissions. The contributions are organized in topical sections named: road; rail; and air. 